\title{
Effect of different level of energy and crude fiber from sawdust in diets on carcass quality of broiler
}

\author{
J. S. Mandey*, Y. H.S. Kowel, M.N. Regar and J. R. Leke \\ Faculty of Animal Husbandry, Sam Ratulangi University, \\ Jl. Kampus Selatan, Manado 95115 - Indonesia \\ *Corresponding E-mail: jetsm_fapet@yahoo.com
}

Received March 01, 2017; Accepted July 28, 2017

\begin{abstract}
ABSTRAK
Penelitian ini bertujuan untuk mengetahui pengaruh level energi dan serat kasar dalam ransum yang mengandung serbuk gergaji terhadap kualitas karkas ayam pedaging. Sebanyak 120 ekor ayam pedaging digunakan dalam penelitian ini. Percobaan menggunakan rancangan acak lengkap pola factorial 2 x 3 dengan 4 ulangan. Perlakuan terdiri dari 2 level energi dan 3 level serat kasar. Ayam dipelihara selama 35 hari dalam kandang baterei, dan pemberian pakan dan air minum dilakukan ad libitum. Variabel yang diamati adalah konsumsi pakan, produksi karkas, lemak abdominal, LDL dan HDL-kolesterol darah. Data dianalisis dengan analisis keragaman dan dilanjutkan dengan uji beda nyata terkecil. Hasil penelitian menunjukkan bahwa perlakuan $3100 \mathrm{Kkal} / \mathrm{kg} \mathrm{ME}$ dan 11\% serat kasar nyata menurunkan konsumsi pakan, persentase lemak abdominal dan LDL-kolesterol darah, tetapi tidak mempengaruhi berat badan akhir dan nilai HDL-kolesterol darah serta tetap mempertahankan nilai persentase karkas yang baik. Dapat disimpulkan bahwa kombinasi perlakuan $3100 \mathrm{Kkal} / \mathrm{kg} \mathrm{ME} \mathrm{dan} \mathrm{11 \%}$ serat kasar pada ransum yang mengandung serbuk gergaji dapat digunakan dalam pakan ayam pedaging.

Kata Kunci: ayam pedaging, energi, kualitas karkas, serat kasar, serbuk gergaji
\end{abstract}

\begin{abstract}
This study was conducted to investigate the effect of different level of energy and crude fiber in diets containing sawdust on carcass quality of broilers. A total of 120 broilers were used for the research. The experiment utilized a completely randomized design in $2 \times 3$ factorial arrangement of treatments consisting of two dietary concentrations of energy and three dietary concentrations of crude fiber. Each treatment consisted of 4 replications ( 5 birds each) was reared during 35 days. The birds were housed in battery cages with ad libitum access to feed and water. During the experiment, feed intake, carcass yield, abdominal fat, blood LDL-cholesterol and HDL-cholesterol were measured. Data were subjected to the analysis of variance test followed by least significant difference test (LSD). Results showed that the diet with $3,100 \mathrm{Kcal} / \mathrm{kg} \mathrm{ME}$ and $11 \%$ crude fiber significantly decreased feed intake, abdominal fat percentage, and blood LDL-cholesterol, but did not affect final body weight and the value of blood HDL-cholesterol and had the good value of carcass percentage. The diets containing sawdust with higher level of energy content decreased feed intake and the higher level of crude fiber decreased final body weight, carcass percentage and abdominal fat. Optimum broiler performance and carcass quality was obtained by diet formulated to contain $3100 \mathrm{Kcal} / \mathrm{kg} \mathrm{ME}$ and $11 \%$ crude fiber.
\end{abstract}

Keywords : broiler, carcass, crude fiber, energy, sawdust 


\section{INTRODUCTION}

Poultry feeding is an important factor in poultry production. The improvement of poultry production is highly depended on synergy between science and practice. By use of modern technology and nutrition knowledge, production of fattening chicken highly increased in the whole world in last 30 years (Steiner et al., 2008).

Dietary fiber is traditionally considered as an anti-nutritional factor (Rougiere et al., 2010). However, moderate amounts of fiber may promote organ development, enzyme production, and nutrient digestibility in poultry. Fibrous feed ingredients have been used in diets of ruminant animals; however, has encouraged researchers to seek a greater understanding of the role of fibrous feedstuffs in diets for non ruminant livestock (Abo Omar, 2005). Use of high dietary fiber feed ingredients in poultry diet has generally been discouraged due to the negative effects exerted on nutrient utilization and performance such as their depression of diet digestibility, and decrease in body weight gain and worsen feed conversion (Kras et al., 2013). However, some types of fiber and fiber sources do not exert such negative effects on nutrient digestibility. Some of these effects result from better gizzard function, with an increase in the gastro duodenal reflux that promotes the contact between nutrients and digestive enzymes (Mateos et al., 2012).

Fiber is a nutritionally, chemically and physically heterogeneous material. It may be divided into soluble fibers which are viscous and fermentable, and insoluble fibers, which are less viscous and fermentable. Both soluble and insoluble fibers have various roles in the digestion and absorption processes in the gastrointestinal tract. Fiber in feed ingredients may affect cecal microbial population and nutrient digestibility. Interactions of these effects can affect bird performance. Thus, nutritionists are faced with a challenge of formulating diets with the available feed ingredients, but also having to mitigate the resulting diet effects to achieve optimum bird production. Wheat bran and cellulose, which are categorized as insoluble fibers, elevate feces weight and fecal bulk and decrease intestinal transit time in non ruminant (Sharikhan et al., 2009). Low apparent metabolizable energy (AME), impaired nutrient absorption and increased incidence of wet droppings may occur due to increase gut viscosity related to feeding soluble non starch polysaccharides (NSP)
(Józefiak et al., 2006). Adding fibrous feedstuffs dilutes the diet and may improve the motility and function of the gastrointestinal tract (GIT). Studies by Shakouri et al. (2006) reported that fiber inclusion diet did not compromise growth in broiler chickens. The beneficial effects of fiber were also shown to be related to decreasing gizzard $\mathrm{pH}$, which was accompanied by enhanced nutrient utilization to support and/or increase growth (González-Alvarado et al., 2007).

Determination of the required amount of energy and protein in feedstuff is also probably the most important decision to be made when it comes to feed formulation for broiler (Steiner, 2008). Hence, formulation of animal feed must take into consideration the nutrient density with energy as the prime factor of the particular feed to facilitate production. The performance of broiler chicks were evaluated by Arabi (2015) that protein level of $20 \%$ and energy level of 3200 $\mathrm{kcal} / \mathrm{kg}$ diet may be recommended for finishing broiler chickens. Increasing dietary energy level will increase weight gain and also improve feed conversion (Araujo et al., 2005; Albuquerque et al., 2003).

The attention now is being focused on cheap but suitable alternative feedstuffs. Utilization of cheaper unconventional or certain locally available feed ingredients in place of conventional one has been widely practiced to mitigate this problem. However, the use of unconventional feedstuff for efficient poultry production is limited due to presence of udigestible components like fiber non starch polysaccharides (Adebiyi et al., 2010). Many forms of residues are produced from wood processing plants. For instance, residues from wood processing plants (the shredded bark, sawdust, and shavings) frequently have no markets, but most untreated woods are quite indigestible. However, Oke and Oke (2007) stated that the sawdust up to $80 \mathrm{~g} \mathrm{~kg}^{-1}$ level of inclusion in broiler diets did not have any detrimental effect on weight gain. Since sawdust is abundant and available throughout the year in many developing countries, the utilization of sawdust will reduce the cost of production. National data of Indonesia according to BPS 2006, production of sawdust from furniture industry were $679.247 \mathrm{~m} 3$ in $600 \mathrm{~kg} / \mathrm{m} 3$ density, equal to 407,508.2 ton.

Generally, whole-tree or tree residues are not considered dangerous to the health of livestock. It is essential, however, that diets containing wood residues be properly balanced for all of the 
Table 1. Chemical Composition of the Diets

\begin{tabular}{lcccccc}
\hline & \multicolumn{6}{c}{ Treatments } \\
\cline { 2 - 7 } Feedstuffs (\%) & \multicolumn{7}{c}{$\mathrm{A} 1$} & $\mathrm{~B} 3$ & $\mathrm{~A} 2$ & $\mathrm{~B} 2$ & $\mathrm{~B} 3$ \\
\cline { 2 - 7 } & $\mathrm{B} 1$ & $\mathrm{~B} 2$ & $\mathrm{~B} 3$ & 52.50 & 45.00 & 38.50 \\
\hline Yellow corn & 47.00 & 44.00 & 34.75 & 9.00 & 9.00 & 8.00 \\
Rice bran & 15.00 & 14.50 & 14.00 & 15.00 & 15.00 & 15.00 \\
Soybean & 10.00 & 11.50 & 12.50 & 8.00 & 8.00 & 8.00 \\
Coconut cake & 15.00 & 12.00 & 14.00 & 12.00 & 13.00 & 14.25 \\
Fish meal & 12.00 & 13.00 & 13.00 & 1.00 & 5.00 & 9.00 \\
Sawdust & 0.25 & 3.50 & 7.25 & 2.00 & 4.50 & 6.75 \\
Coconut oil & 0.25 & 1.00 & 4.00 & 0.50 & 0.50 & 0.50 \\
Top Mix & 0.50 & 0.50 & 0.50 & 100 & 100 & 100 \\
Total & 100 & 100 & 100 & & & \\
Calculated Analysis: & & & & 20.30 & 20.29 & 20.40 \\
Protein (\%) & 20.11 & 20.38 & 20.34 & 5.00 & 8.07 & 11.05 \\
Crude Fiber (\%) & 5.08 & 7.94 & 11.05 & 6.58 & 8.89 & 10.89 \\
Fat (\%) & 5.51 & 6.09 & 8.71 & 0.75 & 0.91 & 0.93 \\
Ca (\%) & 0.75 & 0.83 & 0.86 & 0.78 & 0.78 & 0.79 \\
P (\%) & 0.86 & 0.86 & 0.77 & 3107 & 3104 & 3103 \\
ME (Kcal/kg) & 2801 & 2796 & 2803 & & &
\end{tabular}

$\mathrm{A}=$ energy levels; $\mathrm{B}=$ crude fiber levels

essential nutrients. Wood residues must be considered primarily as energy sources.

The physiological and practical implications of the link between crude fiber and energy intake under iso-protein must then be considered when the dietary requirements for either nutrient are assessed. Moreover, there is a lack of sufficient information about the effect of dietary energy density and crude fiber level on the performance of broiler chickens. Therefore, the aim of this investigation was to study the effect of feeding high and low dietary energy with high and low crude fiber levels on carcass quality of broiler chickens.

\section{MATERIALS AND METHODS}

A total of 120 D.O.C of broilers were used for the research. The experiment utilized a completely randomized design in $2 \times 3$ factorial arrangement of treatments consisting of two dietary concentrations of energy (low and high) and three dietary concentrations of crude fiber. Each treatment consisted of 4 replications (5 birds each) was reared during 35 days. The birds were housed in battery cages in an environmentally controlled room. Feed and water were given ad libitum. During the experimental period (1 to 35 days) chickens were fed iso-protein mixed rations containing different levels of energy and fiber. The crude fiber source of feedstuffs mostly from sawdust and then were mixed with other crude fiber sources. The chemical compositions (dry matter basis) of sawdust were protein $0.66 \%$, crude fat $0.37 \%$, crude fiber $80.31 \%$, NFE $15.79 \%$, Ca $0.79 \%$, P $0.03 \%$, GE $128.51 \mathrm{Kcal} / \mathrm{kg}$. The values for different levels of crude fiber and energy are presented in Table 1 . The value of metabolizable energy was estimated from the gross energy of feed ingredients.

The performance characteristics were feed intake, final body weight, carcass weight, abdominal fat, blood HDL-cholesterol and LDLcholesterol. These parameters were measured 
Table 2. Effect of the Treatment Diets on Carcass Quality

\begin{tabular}{|c|c|c|c|c|c|}
\hline \multirow{2}{*}{ Variables } & \multirow{2}{*}{ Energy Level (A) } & \multicolumn{3}{|c|}{ Crude Fiber Level (B) } & \multirow{2}{*}{$\begin{array}{c}p \text { Value } \\
\mathrm{AxB}\end{array}$} \\
\hline & & $\mathrm{B} 1(5 \%)$ & B2 $(8 \%)$ & B3 $(11 \%)$ & \\
\hline \multirow{2}{*}{ Feed Intake $(\mathrm{g}) \mathrm{b}^{-1} \mathrm{~d}^{-1}$} & A1 $(2800 \mathrm{Kcal} / \mathrm{kg})$ & $127.1^{\mathrm{ab}}$ & $136.1^{\mathrm{c}}$ & $135.4^{\mathrm{c}}$ & \multirow{2}{*}{.001} \\
\hline & A2 $(3100 \mathrm{Kcal} / \mathrm{kg})$ & $124.6^{\mathrm{a}}$ & $129.5^{\mathrm{b}}$ & $124.9^{\mathrm{a}}$ & \\
\hline \multirow{2}{*}{ Final Body Weight (g) } & A1 $(2800 \mathrm{Kcal} / \mathrm{kg})$ & 1786 & 1797 & 1656 & \multirow{2}{*}{673} \\
\hline & A2 $(3100 \mathrm{Kcal} / \mathrm{kg})$ & 1767 & 1766 & 1779 & \\
\hline \multirow{2}{*}{ Carcass $(\%)$} & A1 $(2800 \mathrm{Kcal} / \mathrm{kg})$ & $73.28^{b}$ & $72.47^{b}$ & $70.46^{\mathrm{a}}$ & \multirow{2}{*}{.004} \\
\hline & A2 $(3100 \mathrm{Kcal} / \mathrm{kg})$ & $72.92^{b}$ & $72.93^{\mathrm{b}}$ & $72.62^{b}$ & \\
\hline \multirow{2}{*}{ Abdominal Fat (\%) } & A1 $(2800 \mathrm{Kcal} / \mathrm{kg})$ & $2.02^{\mathrm{b}}$ & $1.93^{\mathrm{ab}}$ & $1.69^{\mathrm{a}}$ & \multirow{2}{*}{.006} \\
\hline & A2 $(3100 \mathrm{Kcal} / \mathrm{kg})$ & $2.49^{\mathrm{c}}$ & $1.79^{\mathrm{a}}$ & $1.64^{\mathrm{a}}$ & \\
\hline \multirow{2}{*}{ HDL-Cholesterol (mg/dl) } & A1 $(2800 \mathrm{Kcal} / \mathrm{kg})$ & 100.2 & 98.3 & 101.9 & \multirow{2}{*}{.884} \\
\hline & A2 $(3100 \mathrm{Kcal} / \mathrm{kg})$ & 99.9 & 97.3 & 103.8 & \\
\hline \multirow{2}{*}{ LDL-Cholesterol (mg/dl) } & A1 $(2800 \mathrm{Kcal} / \mathrm{kg})$ & $100.8^{\mathrm{b}}$ & $108.8^{\mathrm{c}}$ & $104.0^{\mathrm{b}}$ & \multirow{2}{*}{.025} \\
\hline & A2 $(3100 \mathrm{Kcal} / \mathrm{kg})$ & $106.4^{\mathrm{b}}$ & $102.8^{\mathrm{b}}$ & $92.0^{\mathrm{a}}$ & \\
\hline
\end{tabular}

during the finisher period. At the end of the experimental period, one bird from each pen was conventionally slaughtered by cervical dislocation technique, as described in the AVMA Panel on Euthanasia procedure (AVMA, 2001) and its carcass parameters (ready to cook) included dressing percentage and abdominal fat were determined.

Carcass was weighted after removal of feather, head, lungs, gastrointestinal tracts, liver, kidney, abdominal fat. The eviscerated weight was measured to calculate the dressing percentage as the percent of dressed carcass weight to live weight of the bird. Abdominal fat included fat surrounding gizzard, bursa of fabricius, cloaca and adjacent muscles) was removed and weighed individually for 4 chicks per treatment. Blood samples were collected from the wing vein of 5 chicks, in each group, at the end of the experiment (35 days) to analyze cholesterol content.

Data were analyzed by analysis of variance of completely randomized design in $2 \times 3$ factorial arrangement. It was continued to least significant difference test (LSD) (Steel and Torrie, 1994) if the treatment indicated significant effect at a probability level of 5\%. The IBM SPSS Statistics 22 software was used for the statistical processing of data.

\section{RESULTS AND DISCUSSION}

The effects of different energy and fiber levels in diets on carcass quality of broiler chickens is presented in Table 2. Results showed that the daily feed intake was significantly affected by levels of energy and crude fiber, and significantly affected carcass and abdominal fat percentage, and blood LDL-cholesterol. The interaction of energy and crude fiber level final body weight and the value of blood HDLcholesterol. The diet containing $3100 \mathrm{Kcal} / \mathrm{kg} \mathrm{ME}$ and $11 \%$ crude fiber decreased feed intake, abdominal fat percentage, and blood LDLcholesterol, but did not affect final body weight and the value of blood HDL-cholesterol and had good value of carcass percentage.

The result showed that an increase in dietary fiber reduced feed intake in poultry as reported by 
previous researchers (Jimenez-Moreno et al., 2011; Mateos et al., 2012). However, different authors have demonstrated that the inclusion of moderate amounts of insoluble dietary fiber did not affect voluntary feed intake in broilers (Gonzalez-Alvarado et al., 2007; Jimenez-Moreno et al., 2007; Jimenez-Moreno et al., 2009). Moreover, Tooci et al. (2009) reported that dietary dilution of energy treatments did not show significantly difference on feed intake. Tabook et al. (2006) observed high feed intake and no effects on performances when insoluble fiber was included at moderate levels in broiler diets.

The result showed that percentage of abdominal fat significantly decreased although dietary energy level increased, and that was due to high crude fiber level. This result was similar to Shahin and Abdelazim (2006), who reported that abdominal fat, carcass fat and total body fat yields greatly decreased by feeding birds with high fiber diets and produces less abdominal fat depots. At the other side, Mourao et al. (2008) reported that birds fed diets containing insoluble fiber produced lighter carcasses with lower levels of abdominal fat compared with control. Maiorka et al. (2005) announced that dietary energy level affected abdominal fat weight. The abdominal fat increased in the treatments was due to the increasing of dietary energy level.

Since diets high in insoluble fiber contain low energy, birds tended to increase feed consumption to compensate the reducing nutrient concentration in feed. Feed ingredients containing high of insoluble fiber caused an increase in the bulk of the materials that eventually leads to fast passage through the gastrointestinal tracts, unless the animal has a large digestive system capacity. There are suggestions that fiber decreases nutrient digestion because it encapsulates nutrients into the plant cell causing a reduction in the activity of digestive enzymes. Insoluble fiber has been reported to have some beneficial effects. Some experiments have shown that as long as insoluble fiber is included in poultry diets at moderate concentrations, performance of birds will not be affected despite the fact that the nutrient concentration of the diet reduced (Hetland et al., 2004). However, the mechanism of formulating diets with moderate levels of insoluble fiber is not well known.

In this study, the inclusion of crude fiber up to $11 \%$ in diet did not affect final body weight. Oke and Oke (2007) reported that sawdust up to $80 \mathrm{~g} \mathrm{~kg}^{-1}$ level of inclusion in broiler diet did not have any detrimental effect on weight gain. But, Gonzalez-Alvarado et al. (2007) reported that the inclusion of moderate amounts of fiber in low fiber diets might improve chick performance at early ages by reducing gizzard $\mathrm{pH}$ and improving the utilization of nutrients. Sarikhan et al. (2010) reported that suplementing broiler diets up to $0.75 \%$ insoluble raw fiber concentrate did not affect feed intake, increased weight gain and improved FCR.

Shahin and Abdelazim (2005) stated that birds fed a high fiber diets had lower carcass weight than birds fed low fiber diets. This result is in contrast with our results and this differences may be related to fiber source and amounts of fiber in diet. Some of the carcass compositions of the broiler chicken were affected by the different dietary levels of energy and fiber. The significant reduction in carcass in birds fed the diet containing $2800 \mathrm{Kcal} / \mathrm{kg} \mathrm{ME}$ and $11 \%$ crude fiber may be attributed to low dietary calorie.

The body fat deposition significantly increased in birds fed high and normal energy content in the diets resulting into a high calorie: protein ratio which agrees with the report of Swenen et al. (2006). According to Deaton et al. (1983), the highest abdominal fat $(2.29 \%$ of live weight) was produced by broilers offered diet containing $3325 \mathrm{ME} \mathrm{Kcal} / \mathrm{kg}$. The least amount of abdominal fat $(1.92 \%$ of live weight) was produced by broilers offered diets containing 3100 and $3175 \mathrm{Kcal} / \mathrm{kg} \mathrm{ME}$.

The energy content of diet is a key factor to control feed intake in poultry, as broiler chickens eat as much as their energy requirement (Leeson and Summer, 2005). Thus, lower feed intake in this group could be described by higher energy content in the diet.

\section{CONCLUSION}

The diets containing sawdust with higher level of energy content decreased feed intake and the higher level of crude fiber decreased final body weight, carcass percentage and abdominal fat. Optimum broiler performance and carcass quality was obtained by diet formulated to contain $3100 \mathrm{Kcal} / \mathrm{kg} \mathrm{ME}$ and $11 \%$ crude fiber.

\section{REFERENCES}

Abo Omar, J.M. 2005. Carcass composition and visceral organ mass ofbroiler chicks fed different levels of olive pulp. J. Islamic 
Univ. Gaza, Series Nat. Stud. Eng. 13:175184.

Adebiyi, O.A., A.D. Ologhobo, O.A. Adu and T.O. Olasehinde, 2010. Evaluation of the nutritional potentials of physically treated cowpea seed hulls in poultry feed. Emirates J. Food Agric. 22: 232-239.

Albuquerque, R,, D.E. Faria, O.M. Junqueira, D. Salvador and M.F. Rizzo. 2003. Effects of energy level in finisher diets and slaughter age of on the performance and carcass yield in broiler chickens. Bras. Cienc. Avic. 5:2.

Arabi, S.A.M. 2015. The effect of different protein and energy levels on broilers performance under hot climatic conditions. Int. J. Innov. Agric. Biol. Res. 3(1):19-28.

Araujo, L.F., O.M. Junqueira, C.S.S. Araujo, L.C.G.S. Barbosa and J.H. Stringhini. 2005. Energy and lysine for broilers from 44 to 55 days of age. Bras. Cienc. Avic. 7: 11.4.

AVMA. 2001. Report of the AVMA Panel of Euthanasia. AVMA. 218(5):682

Deaton, J.W., J.L. McNaughton and B.D. Lott. 1983. The effect of dietary energy level and broiler weight on abdominal fat. Poult. Sci. 62:2394-2397.

González-Alvarado, J.M., E. Jiménez-Moreno, R. Lázaro and G.G. Mateos. 2007. Effect of type of cereal, heat processing of the cereal, and inclusion of fiber in the diet on productive performance and digestive traits of broilers. Poult. Sci.86: 1705-1715.

Hetland, H., M. Choct and B.Svihus. 2004. Role of insoluble non-starch polysaccharides in poultry nutrition. World's Poult. Sci. Assoc. 60:415-422.

Jiménez-Moreno, E., J.M. Gonzalez-Alvarado, P. Lazaro and G.G. Mateos. 2007. Effects of type of cereal, heat processing of the cereal, and fiber inclusion in the diet on gizzard $\mathrm{pH}$ and nutrient utilization in broilers at different ages. Poult. Sci. 88:1925-1933.

Jiménez-Moreno E., J.M. González-Alvarado,A. González-Serrano, R. Lázaro and G.G. Mateos. 2009. Effect of dietary fiber and fat on performance and digestive traits of broilers from one to twenty-one days of age. Poult. Sci. 88:2562-2574.

Jiménez-Moreno, E.,S. Chamorro, M. Frikha, H.M. Safaa, R. Lázaro and G.G. Mateos. 2011. Effects of increasing levels of pea hulls in the diet on productive performance and digestive traits of broilers from one to eighteen days of age. Anim. Feed Sci.
Technol. 168:100-112.

Józefiak, D., A. Rutkowski, B.B. Jensen and R.M. Enberg. 2006. The effect of beta-glucanase supplementation of barley- and oat-based diets on growth performance and fermentation in broiler chicken gastrointestinal tract. Br. Poult. Sci. 47:5764.

Kras, R.V., A. M. Kessler, A.M.L. Ribeiro, J. Henn, I.I. Santos, D.P. Halfen and L.Bockor. 2013.Effect of Dietary Fiber and Genetic Strain onthe Performance and Energy Balance of BroilerChickens. Brazilian J. of Poult. Sci. 15(1):15-20.

Leeson, S. and J.D. Summers. 2005. Commercial Poultry Nutrition, Nottingham University Press, England.pp. 230-295.

Mateos, G.G., E. Jimenez-Moreno, M.P. Serrano and P. Lazaro. 2012. Poultry response to high levels of dietary fiber sources varying in physical and chemicalcharacteristics. J. Appl. Poult.Res. 21:159-174.

Maiorka, A., F. Dahlke and A.M. Penz. 2005. Diets formulated on total or digestible amino acid basis with different energy levels and physicalform on broiler performance. Revista Bras. Cienc. Avic. 7:47-50.

Mourao J.L., V.M. Pinheiro, J.A.M. Prates, R.J.B. Bessa, L.M.A. Ferreira, C.M.G.A. Fontes and P.I.P. Ponte. 2008. Effect of dietary dehydrated pasture and citrus pulp on the performance and meat quality of broiler chickens. Poult. Sci. 87:733-743.

Oke, B.B. and M.O. Oke. 2007. Effects of feeding graded level of sawdust obtained from Daniellia ogea on the performance and carcass characteristics of broiler chickens. Res. J. Poult. Sci. 1(1):12-15.

Rougiere, N. and B. Carre. 2010. Comparison of gastrointestinal transit times betweenchickens from $\mathrm{D}+$ and $\mathrm{D}-$ genetic lines selected for divergent digestion efficiency. Animal. 4(11):1861-1872.

Sarikhan, M., H.A Shahryar, K. Nazer-Adl, B. Gholizadeh,and B. Beheshti. 2009. Effects of insoluble fiber on serum biochemical characteristics. Int. Agric. Boil. 11:73-75.

Shahin, K.A. and F. Abdelazim, 2005. Effects of breed, sex and diet and their Interaction on carcass composition and tissue weight distribution of broiler chickens. Arch. Tierz. Dummertorf. 48:612-626.

Shahin, K.A. and F. Abdelazim, 2006. Effects of breed, sex and diet and their Interaction on 
fat deposition and partitioning among depots of broiler chickens. Arch. Tierz. Dummertorf. 49:181-193.

Shakouri, M.D., H. Kermanshahi and M. Mohsenzadeh. 2006. Effect of different non starch polysaccharides in semi purified diets on performance and intestinal microflora of young broiler chickens. Int. J. Poult. Sci.. 5(6):557-561.

Steel, R.G.D. and J.H.Torrie. 1994. Principles and Procedures of Statistics. McGraw-Hill Book Co. Inc. Pub. Ltd. London.

Steiner, Z., M. Domacinovic, Z. Antunovic, Z. Steiner,D. Sencic, J. Wagner and D.Kis. 2008. Effect of dietary protein/energy combinations on male broiler breeder performance. Acta Agric. Slovenica.
Suplement 2:107-115.

Swennen, Q., G.P.J. Janssens, A. Collin, E.L. Bihan-Duval, K. Verbeke,E. Decuypere and J. Buyse. 2006.Diet-induced thermogenesis andglucose oxidation in broiler chickens: Influence of genotype and dietcomposition. Poult. Sci. 85:731-742.

Tabook, N.M., I.T. Kadim, O. Mahgoub and W. Al-Marzooqi, 2006. The effect of date fiber supplemented with an exogenous enzyme on the performance and meat quality of broiler chickens. British Poult. Sci. 47:73-82.

Tooci, S., M. Shivazad, N. Eila and A.Zarei. 2009.Effect of dietary dilution of energy and nutrients during different growing periods on compensatory growth of Ross broilers. African J. Biotech. 8(22):6470-6475. 